\title{
EPIDEMIOLOGICAL STUDY ON TRENDS OF JAPANESE ENCEPHALITIS AND ACUTE ENCEPHALITIS SYNDROME IN CACHAR DISTRICT OF ASSAM
}

\author{
Ajit Kumar Dey¹, Atanu Chakravarty² \\ ${ }_{1}^{1}$ Asssitant Professor, Department of Community Medicine, Silchar Medial College, Silchar, Assam, India. \\ ${ }^{2}$ Associate Professor, Department of Microbiology, Jorhat Medical College, Jorhat, Assam, India.
}

\begin{abstract}
BACKGROUND
ABSTRACT

Japanese Encephalitis (JE) over the years has emerged as one of the major public health problems in the country due to its complex eco-epidemiology. JE virus is a leading cause of encephalitis in Asia, causing an estimated 67, 900 JE cases annually. JE/AES has been reported from 171 districts of 19 States in the country. The present study was undertaken to study the trend of AES/JE cases in Cachar District of South Assam.
\end{abstract}

\section{METHODS}

This is a retrospective descriptive study. IDSP surveillance data was examined for the period January 2014 to December 2016. Results were analysed, and appropriate statistical methods was applied.

\section{RESULTS}

Among 300 clinically diagnosed cases of AES, 189 were males (63\%) and rest 111 (37\%) were females. The overall SPR for JE was $16.33 \%$. Significant association was found between age groups and sample positivity rate and in distribution of cases in different block PHCs; with highest SPR observed in 31 to 60 years age group. The CFR in AES and JE Cases was found to be $12.34 \%$ and $12.24 \%$ respectively. The monthly JE cases show seasonal peaks during June to October, coinciding with rainy and post-rainy seasons. Significant correlation of rainfall with prevalence of JE was noticed.

\section{CONCLUSIONS}

JE is endemic in south Assam districts and affects all age groups specially adults. Hence, JE vaccination, integrated vector control management, information, behaviour change communication to be initiated for control of JE.

HOW TO CITE THIS ARTICLE: Dey AK, Chakravarty A. Epidemiological study on trends of Japanese encephalitis and acute encephalitis syndrome in Cachar district of Assam. J. Evolution Med. Dent. Sci. 2019;8(21):1719-1725, DOI: $10.14260 /$ jemds/2019/378

\section{BACKGROUND}

Japanese Encephalitis (JE) over the years has emerged as one of the major public health problems in the country due to its complex eco-epidemiology. ${ }^{1}$ The life cycle of JE virus involves pigs as amplifying hosts, the reservoir of infection are ardeid birds and vectors are the mosquitoes, man are affected incidentally. ${ }^{2}$ In endemic regions, JE occurs mainly among children aged $\leq 15$ years and risk is highest in rural, agricultural areas. No specific treatment for JE is available. ${ }^{3}$

JE is a mosquito-borne disease with a $20 \%-30 \%$ casefatality rate and neurologic or psychiatric sequelae in $30 \%-$ $50 \%$ of survivors. ${ }^{4}$ The cases of JE represent tip of the iceberg compared to the large number of inapparent infections. The ratio of overt disease to inapparent infection varies from $1: 250$ to $1: 1000.1$

The transmission of vector-borne diseases are regulated by the host, the pathogen, and the biology of vectors and their vectorial capacity, which makes the epidemiology complex

'Financial or Other Competing Interest': None.

Submission 03-04-2019, Peer Review 10-05-2019,

Acceptance 16-05-2019, Published 27-05-2019.

Corresponding Author:

Atanu Chakravarty,

Associate Professor,

Jorhat Medical College,

Jorhat-785001, Assam, India.

E-mail: atanu_chakravarty@rediffmail.com

DOI: $10.14260 /$ jemds $/ 2019 / 378$

(c) $($ ) $\$$ and also dependent on environmental factors, e.g., climate and anthropogenic influences, such as changes in agricultural practices, irrigation schemes, and urbanization. $5,6,7,8$

The primary vector of JEV is from the genus Culex, although other mosquitoes are also known to carry the virus. ${ }^{9}$ Rice agriculture areas provide ideal habitat for Culex mosquitoes, and thus risk of acquiring the virus tends to increase with proximity to paddy fields. ${ }^{10,11}$ It is estimated that area dedicated to rice agriculture in Asia increased by $22 \%$ during the period 1963-2003, which has directly contributed to habitat expansion of Culex mosquitoes. ${ }^{12}$

JE was first recognized in Japan in 1924. Since the late 1960s, the size of epidemics in Japan and the People's Republic of China has steadily declined. In contrast, new epidemic foci of JE were reported in the parts of tropical south-eastern Asia as late as 1969.13 Japanese encephalitis (JE) is endemic to large parts of Asia and the Pacific regions. ${ }^{14}$ An estimated 3 billion people are at risk, and the disease has recently spread to new territories globally. ${ }^{10}$ Japanese encephalitis (JE) virus is a leading cause of encephalitis in Asia, causing an estimated 67, 900 JE cases annually. ${ }^{3}$ Twenty-four WHO member states have areas of JE virus transmission risk [Figure-1]. 4

In India, since the first case of JE reported in 1955 from Vellore, Tamil Nadu and subsequently after the first major JE outbreak in 1973 from Burdwan district of West Bengal there has been reports of outbreaks from 171 districts of 19 States in the country. In 2005, a major outbreak of Japanese Encephalitis was reported from eastern UP resulting in more than 6000 cases and 1500 deaths. The Government India in 
response to this introduced Japanese Encephalitis vaccination programme in the high endemic areas from 2006. ${ }^{1}$

Totally, 152 districts of 20 states in the country were affected with JE epidemics from 1955 to 2012. The epidemics of JE death were occurred mainly in the states of Assam, Andhra Pradesh, Tamil Nadu, Karnataka, Kerala, West Bengal, Goa, Uttar Pradesh, Manipur, Haryana, and Bihar during the period of 2007 to $2012^{15}$ [Figure-6a].

The North Eastern Region of India, particularly the upper Assam has been experiencing recurrent episodes of JE with different magnitudes from July to October every year. ${ }^{16}$ Figure- 2 shows the percent contribution of Assam in the prevalence of AES/JE Cases in India during the period from 2010 to 2016. The disease has appeared in sporadic outbreaks or epidemic forms in Assam, since 1976. Climatic conditions, abundance of potential mosquito vectors, amplifying hosts, agricultural practices and the socio-cultural behaviour of the people are conducive to spread JE in the state $^{17}$. Besides Assam, JE cases have been reported from NE states like Manipur and Nagaland ${ }^{18}$. JE case positivity was identified in 10 out of 16 districts in Arunachal Pradesh during the years 2006-2010. Incidentally, all these 10 districts are also highly endemic for malaria, JE transmission season coincided with that of malaria (May to October). ${ }^{19}$

Assam started Children vaccination since 2006 with Sivsagar and Dibrugarh district and in 2007, it included Golaghat \& Jorhat district. In the year 2011, adult JE vaccination was introduced in Sivsagar district with the vaccine SA14-14-2 strain subsequently in 2014, Kamrup (M), Golaghat, Jorhat, Dibrugarh, Tinsukia, Dhemaji and Lakhimpur districts were covered.20 Presently all 27 districts are covered with JE vaccination to children 1-15 yrs. However, adult JE vaccination campaigns has been conducted in 18 districts of Assam.

Assam is currently witnessing an upsurge of JE/AES cases with spread from upper Assam to all other districts and reports of confirmed cases and deaths across the state. ${ }^{21}$ In a hospital based study conducted in Silchar Medical college it was observed that the largest number of AES cases were hailing from Cachar district followed by Karimganj and Hailakandi district of Assam. Few cases were also from adjoining states of Tripura, Meghalaya and Manipur.22

In the above context, the present study was undertaken to study the trend of AES/JE cases in Cachar District of South Assam and to study the demographic profile of study population and the associated factors for distribution of AES/JE cases.

\section{METHODS}

\section{Type of Study}

Retrospective descriptive study.

\section{Study Area}

Cachar district is located in the southernmost part of Assam. It is bounded on the north by Barail and Jayantia hill ranges, on the south by the State of Mizoram and on the west by the districts of Hailakandi and Karimganj. The district lies between $92^{\circ} 24^{\prime} \mathrm{E}$ and $93^{\circ} 15^{\prime} \mathrm{E}$ longitude and $24^{\circ} 22^{\prime} \mathrm{N}$ and type. Cachar receives an average annual rainfall of more than 3, $000 \mathrm{~mm}$. Rainfall increases from March to September with apprehensions of flood, while the month of December and January exhibit very dry period. The temperature is moderate ranging from $13^{\circ} \mathrm{C}-35^{\circ} \mathrm{C}$.

Study Setting- Silchar Medical College hospital (SMCH), Assam.

Time of Study- January 2014 to December 2016.

\section{Study Population}

300 clinically diagnosed Acute Encephalitis Syndrome patients admitted in Silchar Medical College Hospital, Assam who hailed from Cachar district. The line list was validated by District Surveillance Unit, IDSP, Cachar, Assam

\section{Sample Testing}

IgM antibody capture (MAC) ELISA was performed on CSF and serum samples by JE MAC ELISA kit (Kit supplied by National Institute of Virology (NIV), Pune under National Vector Borne Disease Control Programme). The samples were tested in accordance to the procedure guidelines provided by the NIV, Pune.

\section{Data Collection}

Data was obtained, as part of routine AES/JE surveillance from Surveillance site laboratory (SSL) department of Microbiology, SMCH and IDSP unit, department of Community Medicine, SMCH for the corresponding period under study.

\section{Data analysis}

Data was analysed using MS Excel 2007 and SPSS (version 16). Types of Analysis included. Proportions and Percentage, mean, and tests of significance (Chi square test, Goodness of fit etc). $P$ value $<0.05$ was considered significant.

\section{Operational Definition/Case Definitions Acute Encephalitis Syndrome (AES) ${ }^{23}$}

Clinically, a case of AES is defined as a person of any age, at any time of year with the acute onset of fever and a change in mental status (Including symptoms such as confusion, disorientation, coma or inability to talk) AND/OR new onset of seizures (Excluding simple febrile seizures).Other early clinical findings may include an increase in irritability, somnolence or abnormal behaviour greater than that seen with usual febrile illness.

\section{Probable JE (Japanese Encephalitis)}

- A suspected case that occurs in close geographic and temporal relationship to a laboratory confirmed case of JE, in the context of an outbreak. Confirmed JE

- A suspect (AES) or probable JE case confirmed by laboratory tests. Sample Positivity Rate (SPR)

Number of cases whose sample were found reactive for JE/ Number of cases whose sample were tested for JE $\times 100$. 

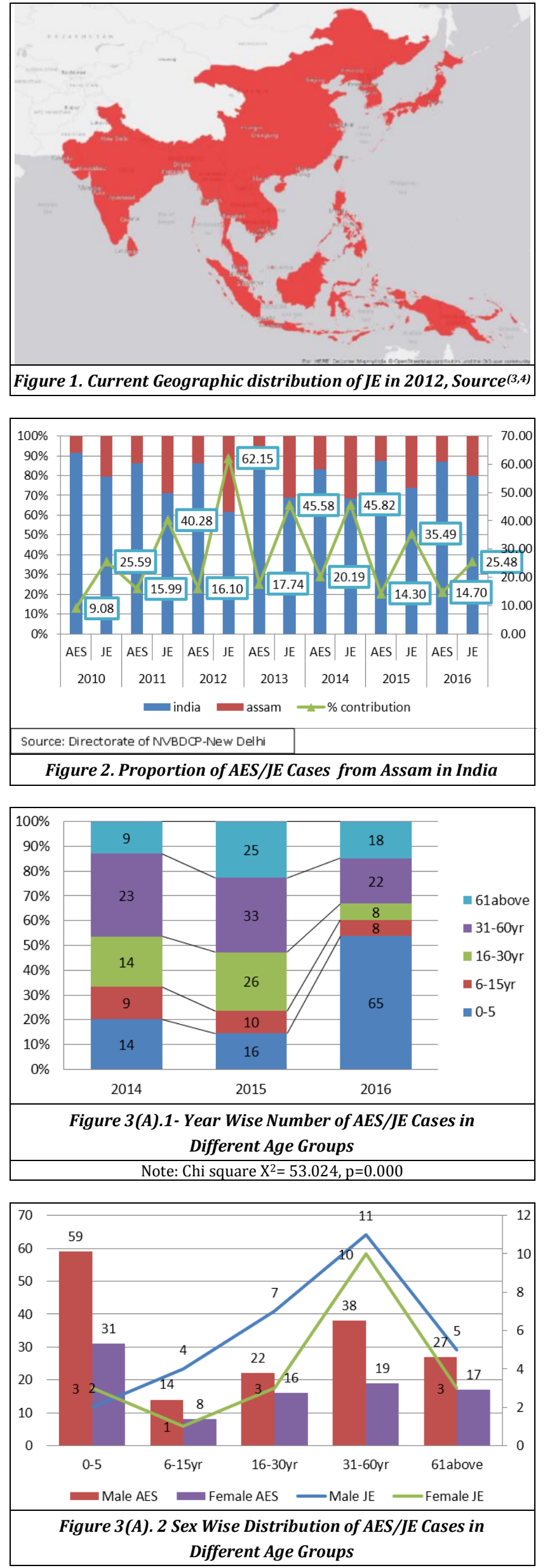
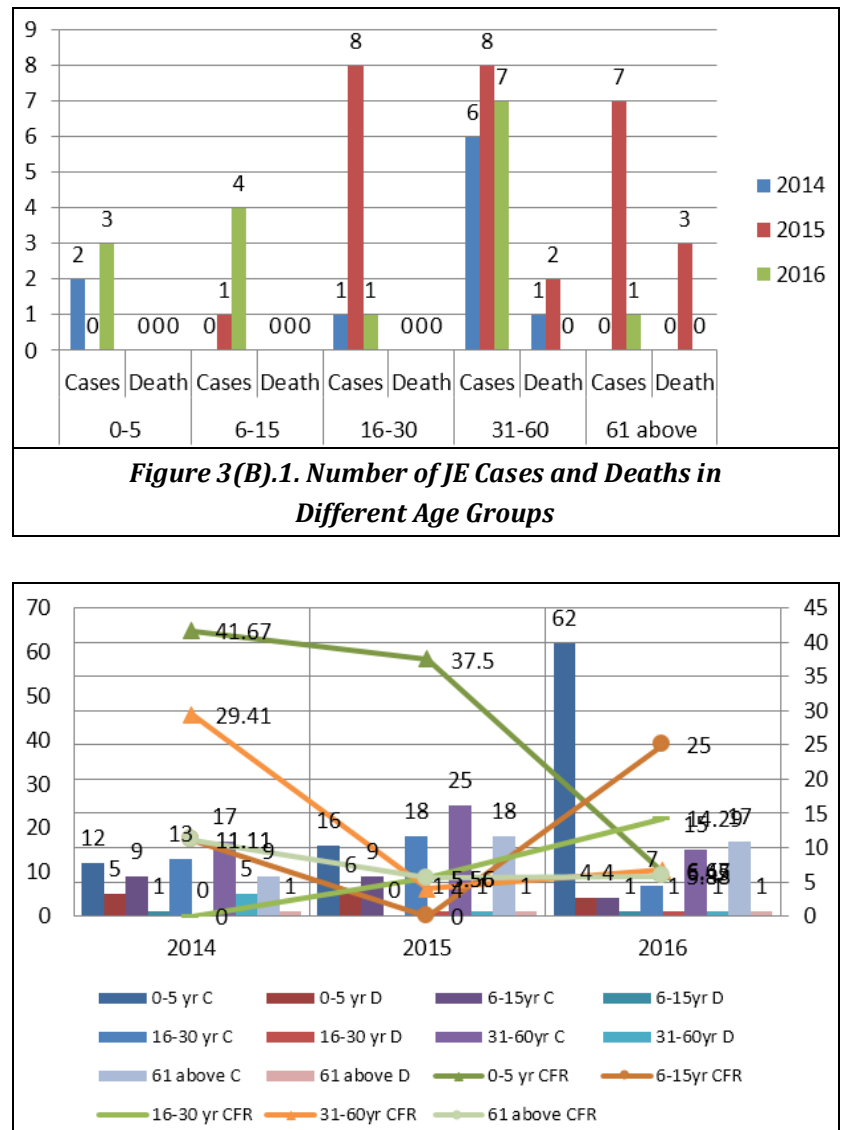

Figure 3(B).2. Number of Case/Death of AES/JE Cases and CFR in 2014, 2015, 2016

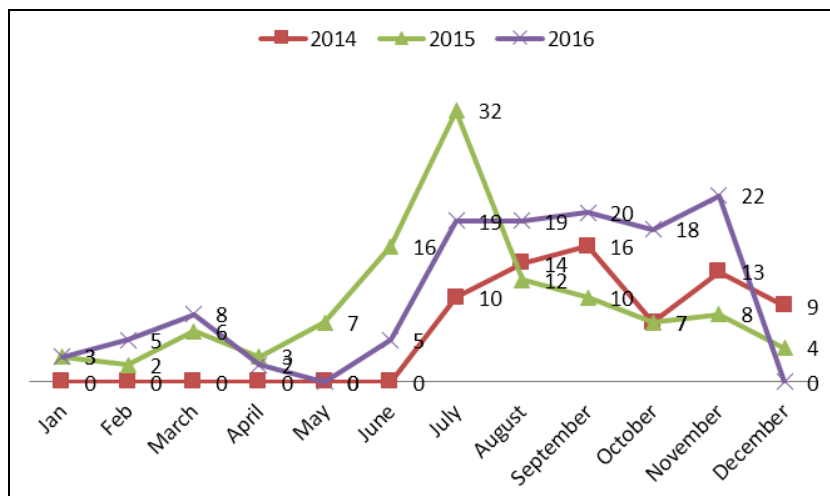

Figure 4.1a. Time Trend of AES/JE Case Reported from Cachar District in 2014, 2015, 2016

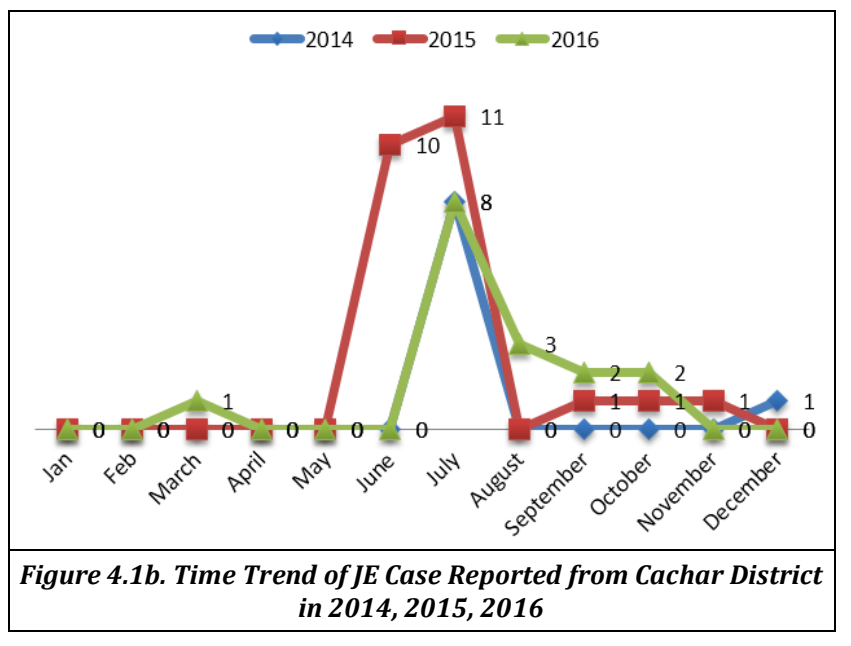




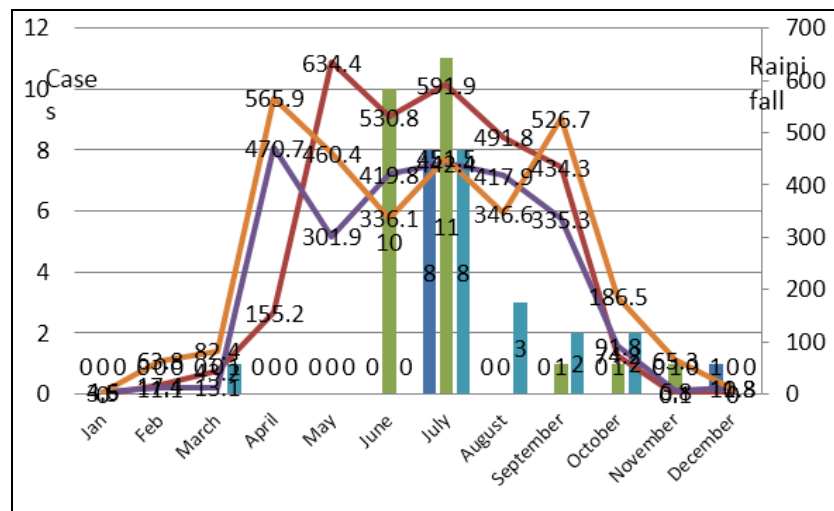

2014 $2015 \longrightarrow 2016 \longrightarrow 2015 \longrightarrow 2016$

Figure 4.2(B). 1 Correlation of Monthly Rainfall \& Japanese Encephalitis Cases in Cachar District in 2014,2015,2016 Note: The monthly rainfall data obtained from the website of Indian Meteorological Department

(www.imd.gov.in/section/hydro/disrainfall/webrain/assam/cachar.txt)
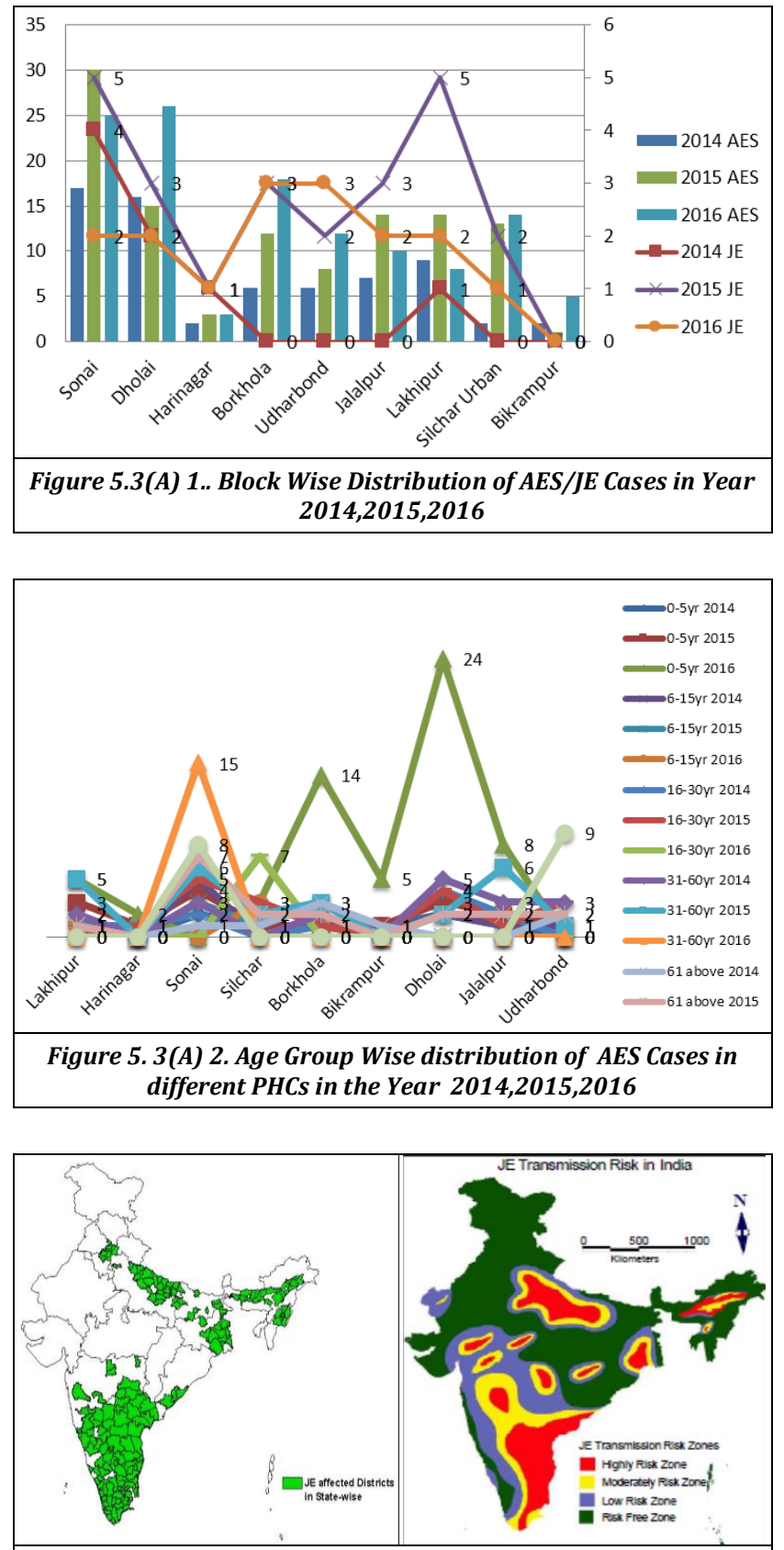

Figure 6a, 6b. JE Prevalence in India (Source: 1,28)

\begin{tabular}{|c|c|c|c|c|c|}
\hline Variable & $\begin{array}{c}\text { AES } \\
(n=251)\end{array}$ & $\begin{array}{c}J E \\
(n=49)\end{array}$ & $\begin{array}{c}\text { Total } \\
(n=300)\end{array}$ & $\begin{array}{l}\text { Positivity } \\
\text { Rate (\%) }\end{array}$ & $\begin{array}{c}\text { Test of } \\
\text { Significance }\end{array}$ \\
\hline \multicolumn{5}{|c|}{ Year } & \\
\hline 2014 & 60 & 9 & 69 & 13.04 & \multirow{3}{*}{$\begin{array}{c}\text { Chi square X2 } \\
=3.825 ; \mathrm{p}= \\
0.430\end{array}$} \\
\hline 2015 & 86 & 24 & 110 & 21.82 & \\
\hline 2016 & 105 & 16 & 121 & 13.22 & \\
\hline \multicolumn{5}{|c|}{ Sex } & \multirow{3}{*}{$\begin{array}{c}\text { Chi square }(\mathrm{X} 2 \\
=0.366 ; \mathrm{p}= \\
0.545\end{array}$} \\
\hline Male & 160 & 29 & 189 & 15.34 & \\
\hline Female & 91 & 20 & 111 & 18.02 & \\
\hline \multicolumn{5}{|c|}{ Religion } & \multirow{4}{*}{$\begin{array}{c}\text { Chi square } \\
\mathrm{X} 2=2.159 \\
\mathrm{p}=0.340\end{array}$} \\
\hline Hindu & 153 & 30 & 183 & 16.39 & \\
\hline Muslim & 95 & 17 & 112 & 15.18 & \\
\hline Christian & 3 & 2 & 5 & 40.00 & \\
\hline \multicolumn{6}{|c|}{ Table 1(A) 1. Distribution of AES/JE Cases and SPR } \\
\hline
\end{tabular}

\begin{tabular}{|c|c|c|c|c|}
\hline Age Group & $\begin{array}{c}\text { AES(n=251) } \\
\text { No (\%) }\end{array}$ & $\begin{array}{c}\text { JE(n=49) } \\
\text { No (\%) }\end{array}$ & Total(n=300) & Positivity (\%) \\
\hline $0-5$ yr. & $90(35.86)$ & $5(10.20)$ & $95(31.67)$ & 5.26 \\
\hline $6-15$ yr. & $22(8.76)$ & $5(10.20)$ & $27((9.00)$ & 18.52 \\
\hline $16-30$ yr. & $38(15.14)$ & $10(20.41)$ & $48(16.00)$ & 20.83 \\
\hline $31-60$ yr. & $57(22.71)$ & $21(42.86)$ & $78(26.00)$ & 26.92 \\
\hline 61 above & $44(17.53)$ & $8(16.32)$ & $52(17.33)$ & 15.38 \\
\hline \multicolumn{6}{|c|}{ Table 1(A) 2. Age Group wise Distribution of AES/JE Cases and } \\
Corresponding Positivity rate of JE in Years 2014, 2015 \& 2016 \\
\hline \multicolumn{6}{|c|}{ Chi square value= 15.760, p value $=0.003$} \\
\hline
\end{tabular}

\begin{tabular}{|c|c|c|c|}
\hline Age Group & $\begin{array}{c}\text { Observed } \\
\text { Number }\end{array}$ & $\begin{array}{c}\text { Expected } \\
\text { Number }\end{array}$ & Residual \\
\hline $0-10$ YR & 6 & 22.0 & -16.0 \\
\hline $11-20$ YR & 8 & 12.0 & -4.0 \\
\hline $21-30 Y R$ & 6 & 3.0 & 3.0 \\
\hline $31-40 Y R$ & 1 & 4.0 & -3.0 \\
\hline $41-5-Y R$ & 9 & 3.0 & 6.0 \\
\hline more than 50 & 19 & 5.0 & 14.0 \\
\hline Total & $\mathbf{4 9}$ & & \\
\hline
\end{tabular}

Table 1(A) 3. Chi Square Test (for Goodness of Fit) for Age Distribution of JE Cases

Note: $\mathrm{Chi}=62.873 ; \mathrm{p}=0.000$

\begin{tabular}{|c|c|c|c|c|c|c|}
\hline & AES Case & Death & JE Case & Death & CFR AES & CFR JE \\
\hline 2014 & 60 & 12 & 9 & 1 & 20.00 & 11.11 \\
\hline 2015 & 86 & 9 & 24 & 5 & 10.47 & 20.83 \\
\hline 2016 & 105 & 8 & 16 & 0 & 8.99 & 0.00 \\
\hline Total & 251 & 29 & 49 & 6 & 12.34 & 12.24 \\
\hline
\end{tabular}

\begin{tabular}{|c|c|c|c|}
\hline Name of Block & Total Case & JE Positive & $\begin{array}{c}\text { Sample } \\
\text { Positivity Rate }\end{array}$ \\
\hline Sonai & $72(24.16)$ & $11(22.92))$ & 15.28 \\
\hline Dholai & $57(19.13)$ & $7(14.58)$ & 12.28 \\
\hline Harinagar & $8(2.98)$ & $3(6.25)$ & 37.50 \\
\hline Borkhola & $36(12.08)$ & $6(12.50)$ & 16.67 \\
\hline Udharbond & $26(8.72)$ & $5(10.42)$ & 19.23 \\
\hline Jalalpur & $31(10.40)$ & $5(10.42)$ & 16.13 \\
\hline Lakhipur & $31(10.40)$ & $8(16.67)$ & 25.81 \\
\hline Silchar Urban & $29(9.73)$ & $3(6.25)$ & 10.34 \\
\hline Bikrampur & $8(2.68)$ & $0(0.00)$ & 0.00 \\
\hline
\end{tabular}

Table-3 (A).1 Block wise number number of AES/JE Cases and SPR Note: Chi square $=6.678 ; \mathrm{p}=0.572$.

\begin{tabular}{|c|c|c|c|c|c|}
\hline Name of PHC & 0-5 Yr. & 6-15 Yr. & $\mathbf{1 6 - 3 0}$ Yr. & 31-60 Yr. & 61 Above \\
\hline Lakhipur & $10(11.36)$ & $4(16.67)$ & $1(2.78)$ & $7(12.07)$ & $2(4.55)$ \\
\hline Harinagar & $3(3.41)$ & $0(0.00)$ & $2(5.56)$ & $0(0.00)$ & $0(0.00)$ \\
\hline Sonai & $6(6.82)$ & $8(33.33)$ & $7(19.44)$ & $24(41.38)$ & $16(36.36)$ \\
\hline Silchar & $5(5.68)$ & $4(16.67)$ & $10(27.78)$ & $2(3.45)$ & $3(6.82)$ \\
\hline Borkhola & $16(18.18)$ & $4(16.67)$ & $2(5.56)$ & $5(8.62)$ & $5(11.36)$ \\
\hline Bikrampur & $7(7.95)$ & $0(0.00)$ & $0(0.00)$ & $0(0.00)$ & $1(2.27)$ \\
\hline Dholai & $29(32.95)$ & $2(8.33)$ & $8(22.22)$ & $7(12.07)$ & $2(4.55)$ \\
\hline Jalalpur & $11(12.50)$ & $1(4.17)$ & $3(8.33)$ & $9(15.52)$ & $2(4.55)$ \\
\hline Udharbond & $1(1.14)$ & $1(4.17)$ & $3(8.33)$ & $4(6.90)$ & $13(29.55)$ \\
\hline \multicolumn{7}{|c|}{ Total } & $\mathbf{8 8}(100.0)$ & $\mathbf{2 4}(100.0)$ & $36(100.0)$ & $\mathbf{5 8}(100.0)$ & $44(100.0)$ \\
\hline Table 3(A) 2. Age Group wise Distribution of AES/JE Cases in Different \\
\hline \multicolumn{7}{|c|}{ PHCs square 107.695; p=0.000 } \\
\hline
\end{tabular}




\section{RESULTS}

\section{1(A). Person Distribution of AES/JE Cases in Relation to} Age, Sex, Religion

Among 300 clinically diagnosed cases of AES, 189 were males (63\%) and rest 111 (37\%) were females. samples of 49 cases were positive for JE; thus, the overall SPR for JE was $16.33 \%$. Year-wise the SPR for 2015 was $21.82 \%$ which is higher than 2014 and 2016 but this was also found to be not significant. SPR was $15.34 \%$ and $18.02 \%$ among males and females, respectively. However, the difference was found to be not significant. There were no significant differences observed in relation to religion also. [Table-1(A).1]

Overall age specific SPR for under 5 years age group was found to be much lower than the SPR in subsequent age groups. Significant association was found between age groups and sample positivity rate; with highest SPR observed in 31 to 60 years age group (Table 1(A).2).

Analysis of AES/JE case in different age groups revealed that $31.67 \%$ cases were below 5 years of age groups, followed by $26.00 \%$ cases were in between 31 and 60 years, $17.33 \%$ cases belonged to the age groups above 61 yrs., $16.00 \%$ cases between $16-30$ years and $9.00 \%$ cases were between $6-15$ yrs. age groups. Moreover, there is a decline in trend in number of cases in age groups 16 years and above during year 2015 and 2016, whereas about 3 times increase is recorded in 0-5 yrs. age group. The difference is found to be statistically significant (Fig-3(A).1).

The proportion of JE cases in different age groups were almost similar for both the sexes with maximum number of JE cases as observed in 31-60 years age group. However, the differences were not significant [X2=19.308, $p=.081]$, Fig$3(\mathrm{~A}) .2$

Further, the present study age distribution of JE cases is compared with the age distribution of JE cases from 2005 2010 of ICMR study. Considering distribution of ICMR study as expected for the total number of cases of the current study and thus observed a significant difference with higher proportion of JE cases found in older age group in the current study (Table-1(A).3.

\section{1(B). Case Fatality Rate (CFR) Among the AES/JE Cases in Relation to Age Group}

Table No-1(B).1 shows overall CFR in AES and JE Cases to be $12.34 \%$ and $12.24 \%$ respectively.

Age group wise analysis of CFR in JE cases showed $42.86 \%$ in above 61 years of age group in year 2015 and $16.67 \%$ and $25 \%$ in age group 31-60 year in year 2014 \& 2015 respectively. [Fig-3(B).1] Comparing to this amongst the AES cases CFR was found to be as $41.67 \%$ \& $37.50 \%$ in 0 5-year age group in the year 2014 \& 2015 respectively. Among both the AES and JE cases the CFR was found to have improved in 2016 in all age groups except in 6-15 and 16-30 years in the AES cases. [Fig-3(B).2]

\section{2(A)Time Distribution of AES/JE Cases}

The AES cases were reported from January onward and continued up to the year end. However, the number of AES/JE cases reached at peak during the period from June to November [Fig-4.1a; 4.1b]. The Monthly reported JE cases show seasonal peaks of JE cases during the months of June to October, coinciding with rainy and post-rainy seasons. With the onset of winter, JE incidence declined substantially.

\section{2(B)Correlation with Monthly Rainfall Data with JE Case Occurrence}

JE cases usually appear in the third month after onset of the monsoon. Vector mosquitoes proliferate profusely subsequent to a monsoon, stimulating an increase of virus activity in mosquitoes and human-mosquito contacts and thus transmission, followed by JE cases. The pattern of rainfall was different in corresponding different years as it is evident from figure 4.2(B) 1 and emergence of JE cases.

\section{3(A) Place Distribution of AES/JE Cases}

Block-wise distribution of total AES/JE cases shows that Sonai PHC has the overall highest number of AES and JE cases as $24.16 \%, 22.92 \%$ followed by Dholai PHC $19.13 \%$ and $14.58 \%$ respectively. And Lakhipur PHC has highest of $16.67 \%$. JE cases, however the SPR was found highest in Harinagar BPHC (37.50\%) followed by Lakhipur BPHC (25.81\%)[Table-3(A).1] the distribution was found to be not significant. Figure-5.3(A)1 shows the year-wise number of AES/JE cases in different Block PHCs. The age groups wise distribution of AES/JE cases in different PHCs suggest significant association. [Table-3(A).2, Fig-5.3(A)2]

\section{DISCUSSION}

Person Distribution of Aes/Je Cases in Relation to Age, Sex, Religion.

\section{Sample Positivity Rate (SPR) for JE}

In the present study SPR was found to be $13.04 \%, 21.82 \%$ and $13.22 \%$ respectively in year 2014, 2015 and 2016 which is lower than in a similar study done in Assam Medical College Hospital, Dibrugarh of Assam where $39.4 \%$ and $51.1 \%$ was observed in year 2007 \& 2008 respectively. ${ }^{24}$ According to the distribution of JE cases in both sexes, the overall SPR among males (12.03\%) was found slightly higher than that among females (10.98\%) from a study done in West Bengal which is in contrast to present findings where higher SPR in case of female $(18.02 \%)$ than in males $(15.34 \%)$ was observed. However, in both the studies the difference was found to be statistically not significant. Moreover, in the same study from West Bengal, there was significant difference seen between year 2011 and 2012 in the prevalence of JE case as from $16.69 \%$ to $7.82 \%$ but the present findings revealed no such significant differences between the year 2014, 2015 \& 2016 respectively. The age specific SPR was found to be similar with the present study. ${ }^{25}$

Corroborating the present findings similar higher prevalence of AES/JE case was observed from Lakhimpur district of Assam in below 5 years of age group ${ }^{26}$ and in West Bengal in below 15 yrs., of age group. On contrary to the JE prevalence of $9.00 \%$ and $17.33 \%$ in the age groups of $6-15$ yrs., and 60 above, the study from West Bengal reported it to be $26.75 \%$ and $7.24 \%$ in the same age group respectively. Moreover, the same study recorded the proportion of cases in the lower age groups (Under 15 years and 15 -30 years) have reduced and the proportion of cases in higher age groups has increased in 2012 than in the year 2011.25 But such trend is not observed in the present study as vaccination against JE has been started recently in south Assam districts. CFR

Comparing to the present finding a study from Lakhimpur district reported higher $(18.20 \%)$ overall case fatality rate 
(CFR) due to AES and maximum CFR was among 0-5 years (34.62\%).26 The death rate of below 10 Years AES patients was found is $69.23 \%$ in another study in Dhemaji district of Assam. ${ }^{20}$ In contrast to the present study the findings from a study conducted in the Department of Paediatrics, Assam Medical College and Hospital, Dibrugarh. Assam reported the mortality was $20.5 \%$ among the JE positive cases in the age group less than 12 yrs. $^{27}$

\section{Time Trend}

Similar time trend has been reported from other parts of the country. ${ }^{28}$ It is evident from different studies that new mutations occurring in JE virus genome due to climatic reasons, which is resulting in the emergence of new environmentally adapted mutant/strains. These are causing very high mortality in rural areas. Further, virus is expanding its boundaries from endemic to non-endemic areas due to availability of large vector population. ${ }^{29}$ In the rural areas of North East India, there is very high mortality because of this new environmentally adapted mutant strains. ${ }^{30}$ Major reasons are presence of vector population and high annual precipitation cycles, demographic patterns, alternate hosts, JE infected human population scattered in different states and

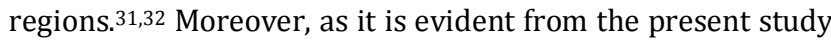
there are large number of AES cases in which the cause is unknown. Hence, the causes of AES need to be explored and to find the geographical distribution of occurrence of such cases.

\section{Place Distribution}

The stratification of areas to high, moderate and low risk of JE transmission has been guided by the remote sensing of JE Epidemic landscape analysis of Normalized Difference Vegetation Index (NDVI) values which are derived from the IRS WiFS data that corresponds to wet rice cultivation areas and the breeding habitats positives for Culex mosquitoes specially during the Kharif and Rabi crop seasons 4-6-8 weeks after rice transplantation, and this also supports for extension of JE epidemic in the newer areas where the wet irrigation rice cultivation is practiced across the country. ${ }^{33}$ [Figure-6b]

\section{CONCLUSIONS}

The AES/JE control seeks to a broader development and rehabilitation challenge rather than merely a medical problem. Immunization is the most cost effective JE prevention strategy and there is a need to put in place a multi-pronged strategy including measures to improve better medical care with adequate infrastructure, awareness, integrated vector control management and larger community involvement. An effective surveillance of AES/JE and timely reporting of cases especially during the transmission period will help prevent deaths and disability from this disease.

\section{ACKNOWLEDGEMENT}

We sincerely acknowledge NIV, Pune for Kits supplied under NVBDCP for routine investigation of AES/JE cases admitted in Medical College.

\section{REFERENCES}

[1] Directorate of National Vector Borne Disease Control Programme (NVBDCP). Operational guidelines on National programme for prevention and control of Japanese encephalitis/Acute Encephalitis Syndrome. 2014 h http://www.nvbdcp.gov.in/Doc/JE-AESPrevention-Control (NPPCJA).pdf.

[2] Samuel PP, Hiriyan J, Gajanana A. Japanese encephalitis virus infection in Mosquitoes and its epidemiological implications. ICMR Bulletin 2000;30(4):37-43.

[3] Baig S, Fox KK, Jee Y, et al. Japanese encephalitis surveillance and immunization-Asia and the Western Pacific, 2012. MMWR Morb Mortal Wkly Rep 2013;62(33):658-62.

[4] Campbell GL, Hills SL, Fischer M, et al. Estimated global incidence of Japanese encephalitis: a systematic review. Bull World Health Organ 2011;89(10):766-74.

[5] Tsai TF. Factors in the changing epidemiology of Japanese encephalitis and West Nile fever. In: Saluzzo J, edr. Factors in the emergence of arbovirus diseases. Paris: Elsevier 1997: p. 179-89.

[6] Kramer LD, Ebel GD. Dynamics of flavivirus infection in mosquitoes. In: Chambers TJ, Monath TP, eds. Flaviviruses: pathogenesis and immunity. San Diego, CA: Academic Press Inc., 2003: p. 187-232.

[7] Cleaveland S, Haydon DT, Taylor L. Overviews of pathogen emergence: which pathogens emerge, when and why? Curr Top Microbiol Immunol 2007;315:85111.

[8] Lindahl J, Chirico J, Boqvist S, et al. Occurrence of Japanese encephalitis virus mosquito vectors in relation to urban pig holdings. Am J Trop Med Hyg 2012;87(6):1076-82.

[9] Solomon T, Ni H, Beasley DW, et al. Origin and evolution of Japanese encephalitis virus in southeast Asia. J Virol 2003;77(5):3091-8.

[10] Erlanger TE, Weiss S, Keiser J, et al. Past, present and future of Japanese encephalitis. Emerg Infect Dis 2009;15(1):1-7.

[11] Miller RH, Masuoka P, Klein TA, et al. Ecological niche modeling to estimate the distribution of Japanese encephalitis virus in Asia. PLoS Neglect Tropica Dis 2012;6(6):e1678.

[12] Keiser J, Maltese MF, Erlanger TE, et al. Effect of irrigated rice agriculture on Japanese encephalitis, including challenges and opportunities for integrated vector management. Acta Tropica 2005;95(1):40-57.

[13] Okuno T. An epidemiological review of Japanese encephalitis. World Health Stat Q 1978;31(2):120-33.

[14] Solomon T. Control of Japanese encephalitis-within our grasp? N Engl J Med 2006;355(9):869-71.

[15] Palaniyandi M. GIS for mapping updates of spatial spread and the ecological reasoning of JE transmission in India (1956-2012). Journal of Geomatics 2013;7(2):126-33.

[16] Dutta P, Khan SA, Khan AM, et al. The effect of Insecticide-Treated Mosquito Nets (ITMNs) on Japanese encephalitis virus seroconversion in pigs and humans. Am J Trop Med Hyg 2011;84(3):466-72. 
[17] Phukan AC, Borah PK, Mahanta J. Japanese encephalitis in Assam, Northeast India. Southeast Asian J Trop Med Public Health 2004;35(3):618-22.

[18] Chattopadhyay UK. A study on the status of Japanese encephalitis infection in Arunachal Pradesh. J Commun Dis 2001;33(4):261-5.

[19] Khan SA, Dutta P, Khan AM, et al. Japanese encephalitis epidemiology in Arunachal Pradesh, a hilly state in northeast India. Asian Pacific Journal of Tropical Disease 2011;1(2):119-22.

[20] Mridul M, Abhishek M. Prevalence of Japanese encephalitis in Dhemaji District of Assam. JAFS 2015;1(1):119-23.

[21] Dev V, Sharma VP, Barman K. Mosquito-borne diseases in Assam, north-east India: current status and key challenges. WHO South-East Asia J Public Health 2015;4(1):20-9.

[22] Atanu C, Debadatta D, Borthakur AK, et al. Japanese encephalitis in South Assam: a hospital based study. Journal of Science 2016;6(9):463-66.

[23] National Centre for Disease Control. New Delhi: Integrated Disease Surveillance Project. Training manual for medical officers for hospital based disease surveillance. 2nd edn. 2006: p. 23.

[24] Borthakur AK, Das N, Bora B. Data from the World Health Organization (WHO) national network laboratory for Japanese encephalitis. J Global Infect Dis 2013;5(2):76-9.

[25] Chakraborty D, Banerjee S, Maji D, et al. A descriptive study of Japanese encephalitis in West Bengal, India, based on surveillance data: changing pattern observed in recent years. Sch J App Med Sci 2015;3(1E):320-8.
[26] Sharma J, Gogoi D, Soni M, et al. Epidemiological and etiological study of acute encephalitis syndrome cases: a study from Lakhimpur district of Assam. Trop J Med Res 2017;20(1):109-11.

[27] Gogoi A, Panyang R, Baro L, et al. Acute encephalitis syndrome in children with special reference to Japanese encephalitis: a retrospective analysis. J Evolution of Med Dent Sci 2016;5(51):3289-94.

[28] Kumari R, Joshi PL. A review of Japanese encephalitis in Uttar Pradesh, India. WHO South-East Asia Journal of Public Health 2012;1(4):374-95.

[29] Rodhain F. Japanese encephalitis: a fast-changing viral disease. Bull Soc Pathol Exot 2010;103(3):135-54.

[30] Upadhyay RK. Evolution of new variants/mutants of JE virus, its effect on neurovirulence, antigenicity, host immune responses and disease transmission in endemic areas. Article ID 516904, Journal of Viruses 2014: p. 1-35.

[31] Turtle L, Griffiths MJ, Solomon T. Encephalitis caused by flaviviruses. QJM 2012;105(3):219-23.

[32] Upadhyay RK. Epidemiology, disease Transmission and pathogenesis caused by JE virus: its prevention and control. American Journal of Infectious Diseases and Microbiology 2015;3(1):38-64. http://pubs.sciepub.com/ajidm/3/1/6.

[33] Palaniyandi M. The red and infrared IRS WiFS satellite data for mapping of Malaria and JE Vector mosquito breeding habitats. J Geophys Remote Sensing \& GIS 2014;3(3):126. doi:10.4172/2169-0049.1000126 